\title{
WAJIB SIMPAN RAHASIA KEDOKTERAN VERSUS KEWAJIBAN HUKUM SEBAGAI SAKSI AHLI
}

\author{
Ratna Winahyu Lestari Dewi \\ Fakultas Hukum Universitas Wijaya Kusuma Surabaya \\ e-mail: ratnawldewi@yahoo.co.id
}

\begin{abstract}
ABSTRAK
Hubungan antara dokter dan pasien dilandasi rasa kepercayaan sehingga pasien bersedia menceritakan segala hal tentang penyakitnya. Informasi yang diketahui oleh dokter pada saat melakukan pemeriksaan maupun segala sesuatu yang diceritakan oleh pasien tersebut dikenal sebagai rahasia kedokteran dan wajib disimpan. Dokter akan menghadapi situasi yang dilematis jika kewajiban untuk menyimpan rahasia kedokteran ini dihadapkan dengan kewajiban dokter yang lain yaitu memberikan bantuan hukum sebagai saksi ahli di persidangan.

Kata Kunci: wajib simpan, rahasia kedokteran, dokter, pasien, saksi ahli.

ABSTRACT

The relationship between a doctor and patient based on a sense of trust so that the patient is willing to tell everything which is related to illness. All information that known by the doctor at the time of examination as well as those information that described by the patient are known as medical secrets. They must be kept as secret. Doctors will face a dilemma situation if the obligation to keep medical secret is confronted with other obligations that provide legal aid as an expert witness in court.
\end{abstract}

Keywords: compulsory savings, secrets of medicine, doctors, patients, expert witnesses.

\section{PENDAHULUAN}

Kata versus dalam judul tersebut sengaja penulis gunakan untuk menggambarkan betapa hebatnya pertarungan batin yang dialami oleh seorang dokter jika dihadapkan pada satu pilihan, menyimpan rahasia kedokteran yang menjadi kewajiban berdasarkan sumpah yang sudah diucapkannya atau membuka rahasia tersebut karena kewajibannya untuk memberi bantuan hukum di persidangan. Kedua kewajiban tersebut sama-sama memberikan sanksi jika dilanggar maupun jika tidak dipenuhi.

Sebelum penulis ulas lebih jauh masalah klasik yang terkait dengan rahasia kedokteran ini, maka akan penulis telaah terlebih dahulu mengenai hubungan antara pasien dan dokter. Hubungan yang dikenal dengan istilah transaksi terapeutik ini dilandasi oleh rasa kepercayaan. Tanpa adanya kepercayaan pada dokter yang akan mengobatinya, mustahil seorang pasien akan mau menceritakan segala hal yang dialami dan dirasakan terkait dengan penyakitnya.

Dokter merupakan pihak yang telah mempunyai keahlian di bidang kedokteran, sedangkan pasien adalah orang sakit yang membutuhkan bantuan dokter untuk menyembuhkan penyakit yang dideritanya. Pada kedudukan ini, dokter itu adalah orang yang dianggap pakar dalam bidang kedokteran dan pasien adalah orang sakit yang awam akan penyakitnya dan mempercayakan dirinya untuk disembuhkan oleh dokter (Safitri Hariyani, 2005:9).

Hubungan antara dokter-pasien, terutama ditandai prinsip-prinsip etis yang utama, antara lain Berbuat baik, yaitu tidak melakukan sesuatu yang merugikan (non-nocere). Dalam berbuat baik ini dokter dituntut untuk rela berkorban walaupun dia sendiri mengalami kesulitan. Misalnya malam hari seorang dokter harus datang menolong pasien walaupun ia sendiri dalam keadaan lelah dan sedang istirahat; Keadilan, yaitu memberikan perlakuan yang sama kepada setiap orang pada situasi yang sama tanpa memandang jasa, kekayaan, status sosial dan kemampuan membayar dari pasiennya; Otonomi, yaitu hak atas perlindungan privacy pasiennya.

Dokter sebagai seseorang yang profesional di bidangnya berkewajiban menyarankan kepada pasien untuk memilih tindakan medis yang akan dilakukan kepada dirinya, karena keputusan mengenai tindakan medis yang akan dilakukan terhadap diri pasien adalah hak pasien untuk menentukan dirinya sendiri. Dalam hal ini dikatakan bahwa dokter memiliki kebebasan profesional, sedangkan pasien memiliki kebebasan terapeutik (Anny Isfandyarie, 2005:4). 
Transaksi terapeutik merupakan perjanjian antara dokter dengan pasien, berupa hubungan hukum yang melahirkan hak dan kewajiban bagi kedua belah pihak. Berbeda dengan transaksi yang biasa dilakukan oleh masyarakat, transaksi terapeutik memiliki sifat atau ciri yang khusus yang berbeda dengan perjanjian pada umumnya, kekhususannya terletak pada atau mengenai obyek yang telah diperjanjikan. Obyek dari perjanjian ini ialah berupa upaya atau terapi untuk kesembuhan pasien. Jadi perjanjian atau transaksi terapeutik, adalah suatu transaksi untuk menentukan atau upaya mencari terapi yang paling tepat bagi pasien yang dilakukan oleh dokter. Jadi menurut hukum, obyek perjanjian dalam transaksi terapeutik bukan kesembuhan pasien, melainkan mencari upaya yang tepat untuk kesembuhan pasien (Bahder Johan Nasution, 2005:11).

Dalam perjanjian terapeutik apakah juga berlaku ketentuan-ketentuan umum dari hukum perikatan sebagaimana yang telah diatur dalam Buku III Kitab Undang-Undang Hukum Perdata (yang selanjutnya akan disebut KUHPerdata). Sebagaimana umumnya dalam suatu perikatan, dalam transaksi terapeutik juga terdapat para pihak yang mengikatkan diri dalam suatu perikatan atau perjanjian, yaitu dokter yang melaksanakan atau memberikan pelayanan medis dan pasien sebagai pihak yang melaksanakan atau memberikan pelayanan medis dan pasien sebagai pihak yang menerima pelayanan medis. Jadi, secara umum apa yang diatur dalam perjanjian menurut Buku III KUHPerdata, diatur juga atau berlaku pula dalam perjanjian terapeutik. Hanya saja dalam perjanjian terapeutik, ada kekhususan tertentu, yaitu tentang ikrar atau cara mereka mengadakan perjanjian, sebab dalam perjanjian terapeutik dijelaskan bahwa dengan kedatangan pasien ke tempat praktik atau ke rumah sakit tempat dokter bekerja, dengan tujuan untuk memeriksakan kesehatannya atau untuk berobat, sudah dianggap ada perjanjian terapeutik (Bahder Johan Nasution, 2005:11-12).

Dalam hukum perikatan sebagaimana diatur dalam KUHPerdata, dikenal adanya dua macam perjanjian yaitu, Inspanningsverbintenis, yakni perjanjian upaya, artinya kedua belah pihak yang berjanji berdaya upaya secara maksimal untuk bisa mewujudkan apa yang diperjanjikan; dan Resultaatverbintenis, yakni suatu perjanjian bahwa pihak yang berjanji akan memberikan suatu resultaat, yaitu suatu hasil yang nyata sesuai dengan apa yang diperjanjikan.

Perjanjian antara dokter dengan pasien termasuk pada perjanjian inspanningsverbintenis atau perikatan upaya, sebab dalam konsep ini seorang dokter hanya berkewajiban untuk melakukan pelayanan kesehatan dengan penuh kesungguhan, dengan mengerahkan seluruh kemampuan dan perhatiannya yang sesuai standar profesinya. Penyimpangan yang dilakukan oleh seorang dokter dari prosedur medis, itu berarti melakukan tindakan ingkar janji atau cedera janji seperti yang diatur dalam Pasal 1239 KUHPerdata. Jika seorang pasien atau keluarganya menganggap bahwa dokter tidak melakukan kewajiban-kewajiban kontraktualnya, pasien tersebut dapat menggugat dengan alasan wanprestasi dan menuntut agar mereka memenuhi syarat-syarat tersebut. Pasien juga dapat menuntut kompensasi secara materiil dan immaterial atas kerugian yang telah dideritanya. Jika perbuatan atau tindakan dokter yang bersangkutan berakibat merugikan pasien dan merupakan perbuatan yang melawan hukum, maka ketentuan Pasal 1365 dan 1366 KUHPerdata dapat dijadikan dasar gugatannya walaupun tidak ada hubungan kontraktual. Gugatan yang berdasarkan perbuatan melanggar hukum, dapat diterima jika terdapat fakta-fakta yang mendukung bahwa kerugian pasien mempunyai sebab akibat dengan tindakan seorang dokter, gugatan dengan dasar perbuatan melawan hukum dapat diajukan, terlepas dari ada atau tidak adanya kontrak yang mewujudkan perbuatan melanggar hukum (Bahder Johan Nasution, 2005:13-14).

Pada awalnya hubungan antara seorang dokter dengan pasien dalam ilmu kedokteran umumnya berlangsung sebagai suatu hubungan biomedis aktif pasif. Dalam hubungan tersebut rupanya hanya ada kegiatan pihak dokter, sedangkan pasien tetap pasif. Hubungan ini berat sebelah dan tidak sempurna karena merupakan suatu pelaksanaan wewenang oleh yang satu terhadap yang lainnya. Upaya perawatan dan pelayanan kesehatan merupakan suatu alur proses yang dinamik yang berlanjut pada permasalahan ekonomi. Pola dasar hubungan pasien-dokter dalam pelayanan kesehatan dibedakan dalam 3 (tiga) pola hubungan, yaitu:

Pertama, Activity-Pasivity, yaitu Pola hubungan orangtua dan anak seperti ini merupakan pola klasik sejak saat profesi kedokteran mulai mengenal kode etik. Disini seolah-olah dokter dapat sepenuhnya melaksanakan umumnya tanpa campur tangan pasien dengan suatu motivasi altruistis. Biasanya hubungan ini berlaku pada pasien yang keselamatan jiwanya terancam atau sedang tidak sadar atau menderita gangguan mental berat.

Kedua, Guidance Cooperation, yaitu hubungan membimbing kerjasama seperti halnya para orangtua dengan remaja. Pola hubungan ini ditemukan bila 
keadaan pasien tidak terlalu berat misalnya penderita infeksi baru atau penyakit akut lainnya. Meskipun sakit pasien tetap sadar dan memiliki kemauan serta perasaan sendiri. Ia berusaha mencari pertolongan pengobatan dan bersedia bekerjasama. Walaupun dokter mengetahui lebih banyak, ia tidak sematamata menjalankan kekuasaan, namun mengharapkan kerjasama pasien yang diwujudkan dengan menuruti nasehat atau anjuran dokter.

Ketiga, Mutual Participation. Filosofi pola ini berdasarkan pada pemikiran bahwa setiap manusia memiliki martabat dan hak yang sama. Pola ini terjadi pada mereka yang ingin memelihara kesehatannya seperti medical check-up atau pada pasien penyakit kronis. Pasien secara sadar akan berperang dalam pengobatan terhadap dirinya. Hal ini tidak dapat diterapkan pada pasien berlatar belakang pendidikan dan sosial yang rendah atau pasien anak dengan suatu gangguan mental tertentu (Danny Wiradharma, 1996: 25-26).

Sebagaimana yang telah diuraikan sebelumnya, hubungan antara dokter dan pasien dilandasi dengan kepercayaan yang sangat tinggi. Pasien bersedia menceritakan segala hal-hal yang terkait dengan penyakitnya karena dia percaya bahwa rahasia itu akan disimpan oleh dokter yang mengobati atau merawatnya. Hak pasien atas kerahasiaan ini adalah bagian atas prinsip moral otonomi, pada bagian dari otonomi seseorang salah satunya adalah menentukan siapa saja yang boleh mengetahui tentang dirinya. Konsultasi medis dapat terjadi dengan pengungkapan informasi kepada seorang dokter, yaitu dengan tujuan untuk mengobati pasien dan bukan untuk alasan yang lain. Informasi ini adalah milik pasien yang mengungkapkan informasi dan tidak boleh diberikan pada orang ketiga tanpa persetujuan yang bersifat spesifik (Abdul Mun'im Idries dan Agung Legowo Tjiptomartono, 2008:252).

Penyampaian informasi oleh si pasien tentang penyakitnya dengan jujur dan terbuka jika terdapat komunikasi dengan pihak dokter berlangsung lancar dan berjalan dengan baik. Komunikasi antara pasien dengan dokter ini harus didasarkan pada sikap saling percaya antara satu dengan yang lain. Sikap saling percaya ini akan merubah suasana situasional yang timbul dalam hubungan dokter dengan pasien. Dokter sangat diharapkan menyadari faktor psikologis yang dihadapi pasien di ruang praktiknya atau pun di rumah sakit karena faktor pengalaman, rasa takut karena trauma, rasa rendah diri. Bila dokter dapat bertindak dengan sabar, menghormati hak-hak pasien, membuat pasien tidak takut dan merasa rendah diri diharapkan sikap dokter yang demikian ini akan membuat pasien menaruh suatu kepercayaan kepada dokter yang akan merawatnya (Hendrojono Soewono, 2007:77).

Sikap dan perilaku seorang dokter yang demikian akan menumbuhkan kepercayaan pasien bahwa dokter yang dihadapi merupakan orang yang harus dihormati karena merupakan orang yang akan membantu penyembuhan penyakit yang dideritanya. Pasien diharapkan akan menemukan jati dirinya pada siapa dia berhadapan, sehingga tanpa ragu pasien akan menceritakan semua gejala penyakit yang dideritanya kepada orang yang dipercaya akan membantu menyembuhkan penyakit yang diderita. Dan kondisi ini sangat menguntungkan pihak dokter untuk mendapatkan semua data tentang kondisi penyakit dari pihak pasien yang dirawatnya. Dengan diperolehnya data lengkap dari penyakit pasien, dokter akan dengan mudah, teliti dan seksama melakukan diagnosa tertentu terhadap penyakit yang diderita pasien untuk selanjutnya menentukan terapi apa yang akan dilakukannya. Pada hakikatnya komunikasi antara dokter dengan pasien harus didasarkan pada kebenaran informasi. Kebenaran atas informasi dokter dengan pasien dapat terjadi, bila kedua belah pihak bersifat terbuka. Pihak pasien tidak merasa dirinya ditekan oleh dokter, tidak ada perasaan takut, merasa dihormati sebagai manusia yang mempunyai harga diri, dan kondisi demikian ini didorong oleh rasa keinginan disembuhkannya penyakit yang diderita, pasien akan menyerahkan dirinya untuk dirawat oleh dokter yang dipercayainya (Hendrojono Soewono, 2007:78).

Dari uraian di atas tersebut tergambar jelas bahwa pelayanan kesehatan merupakan suatu profesi yang didasarkan atas kerahasiaan dan kepercayaan seperti halnya profesi pengacara. Menurut Van der Mijn, ciri pokok dalam pelayanan kesehatan sebagai berikut:

Pertama, Setiap orang yang meminta pertolongan secara profesional umumnya akan berada pada posisi ketergantungan, artinya bahwa ia harus meminta semacam pertolongan tertentu dengan maksud dan untuk mencapai suatu tujuan khusus. Misalnya,untuk tujuan peningkatan kesehatannya seseorang minta pertolongan kepada profesi dokter, kalau seseorang mempunyai tujuan melakukan suatu tuntutan hukum datang kepada profesi pengacara, sedang untuk tujuan menyatakan kehendaknya (membuat wasiat) minta pertolongan kepada profesi notaris.

Kedua, Setiap orang yang meminta pertolongan dari orang yang mempunyai profesi yang bersifat rahasia, pada umumnya tidak dapat menilai keahlian profesi itu. 
Ketiga, Hubungan antara orang yang meminta pertolongan dan orang yang memberi pertolongan bersifat rahasia dalam arti bahwa pihak yang pertama bersedia memberi keterangan-keterangan yang tidak akan ia ungkapkan kepada orang lain, dan pihak profesi harus bisa menjaga kerahasiaan tersebut.

Keempat, Setiap orang yang menjalankan suatu profesi yang bersifat rahasia, hampir selalu memegang posisi yang tidak bergantung (bebas), juga apabila ia berpraktik swasta. Malah dalam kasus demikian, ada otonomi profesi dan hanya beberapa kemungkinan saja bagi pihak majikan untuk melakukan tindakantindakan korektif.

Kelima, Sifat pekerjaan ini membawa konsekuensi pula bahwa hasilnya tidak pasti selalu dapat dijamin, melainkan hanya ada kewajiban untuk melakukan yang terbaik. Kewajiban itu tidak mudah untuk diuji (D. Veronica Komalawati, 1989:14-15).

Dari ciri-ciri pokok pelayanan kesehatan itu dapat disimpulkan bahwa dengan penuh kepercayaan, seorang pasien akan pasrah kepada dokter dengan keyakinan bahwa ilmu yang dimiliki dokter tersebut, akan digunakan untuk menolongnya sehingga terlepas dari penderitaannya. Sebab itu syarat utama untuk memperoleh hasil yang baik dalam merawat pasien ialah kepercayaan pasien kepada dokternya (Anny Isfandyarie, 2005:13).

Berbicara tentang rahasia, dapat dipastikan bahwa seseorang pasti memiliki rahasia dalam kehidupan pribadinya. Rahasia itu akan disimpannya rapatrapat, akan selalu dijaga jangan sampai ada pihak lain yang mengetahuinya. Sedangkan menurut Peraturan Pemerintah Nomor 10 Tahun 1966 tentang Wajib Simpan Rahasia Kedokteran (selanjutnya disingkat PP No. 10 Tahun 1966), yang dimaksud dengan rahasia kedokteran ialah segala sesuatu yang diketahui oleh orang-orang tersebut dalam Pasal 3 pada waktu atau selama melakukan pekerjaannya dalam lapangan kedokteran. Sementara dalam Pasal 3 disebutkan bahwa yang diwajibkan menyimpan rahasia tersebut adalah: tenaga kesehatan yaitu tenaga medis, yaitu meliputi apoteker, analisis farmasi, asisten apoteker; tenaga kesehatan masyarakat meliputi epidemiolog kesehatan, dan entomolog kesehatan, mikrobiolog kesehatan, penyuluh kesehatan, dan administrator kesehatan dan sanitarian; tenaga gizi itu meliputi nutrionis dan dietisien; tenaga keterapian fisik itu meliputi fisioterapis, okupasiterapis, terapis wicara; tenaga keteknisan medis itu meliputi radiographer, radioterapis, teknisi gigi, teknisi elektromedis, analisis kesehatan, refraksionis optisien, otorik prostetik, teknisi transfuse dan perekam medis. Selain para tenaga kesehatan yang sudah disebutkan itu, maka pihak lain yang juga diwajibkan untuk menyimpan rahasia kedokteran adalah mahasiswa kedokteran, murid yang bertugas dalam lapangan pemeriksaan, pengobatan, dan/atau perawat yang ditetapkan oleh Menteri Kesehatan.

Perlindungan hukum yang telah diberikan dalam kerahasiaan hubungan dokter dengan pasien bukan hanya terhadap suatu kerahasiaan dalam hubungan langsung antara dokter dan pasien, akan tetapi lebih luas lagi sesuai dengan doktrin perlindungan hasil kerja. Doktrin perlindungan hasil kerja ialah bahwa perlindungan terhadap kerahasiaan antara dokter dan pasiennya bukan hanya rahasia yang terbit dari hubungan langsung (konsultasi) antara dokter dan pasiennya, melainkan termasuk juga perlindungan kerahasiaan dari informasi yang didapatkan dokter dari sumber lain yang berkaitan dengan pasien yang bersangkutan (Munir Fuady, 2005:31).

Rahasia kedokteran sejak zaman Hippocrates, telah disadari memiliki alasan yang mendasar untuk dipertahankan dalam hubungan dokter pasien. Justice Clark merumuskan berbagai alasan ini menjadi 3 (tiga) alasan utama, yaitu: Tanpa jaminan kerahasiaan, maka orang yang membutuhkan pengobatan akan berusaha untuk bisa menahan diri untuk mencari bantuan dokter (deterrence from treatment), dan Jaminan kerahasiaan menjadi kebutuhan essensial agar pasien mengungkapkan seluruh keluhan terkait dengan penyakitnya dengan jujur (full disclosure), serta Kerahasiaan adalah suatu bagian integral untuk bisa mencapai pengobatan yang berhasil (successful treatment) (Abdul Mun'im Idries dan Agung Legowo Tjiptomartono, 2008:253).

Tidak semua informasi atas pengakuan, dokumen, data, jiwa dan raga, atau informasi yang diperoleh dokter dari seorang pasiennya atau dari pihak lain yang berhubungan dengan pasiennya itu merupakan kerahasiaan yang akan dilindungi oleh hukum (Wila Chandrawila Supriadi, 2001:56).

Kerahasiaan tertentu itu saja yang merupakan rahasia yang dilindungi, yakni rahasia-rahasia yang memenuhi syarat sebagai berikut: Rahasia tersebut merupakan informasi yang substansial dan penting bagi pasien atau bagi pengobatannya; Rahasia tersebut sebelumnya belum pernah terbuka untuk umum secara meluas. Apabila rahasia tersebut telah terbuka untuk umum tetapi belum meluas atau jika rahasia tersebut sudah dibuka sebagai alat bukti, rahasia tersebut tetap tidak boleh dibuka oleh dokter kepada orang lain; Rahasia tersebut bukanlah informasi yang memang tersedia untuk publik; dan Rahasia yang jika dibuka 
akan menimbulkan rasa malu bagi pasien, dokter, atau pihak-pihak lainnya; Rahasia yang jika dibuka akan merugikan kepentingan pasiennya; Rahasia yang jika dibuka maka akan mempersulit pengobatan dokter kepada pasiennya; Rahasia yang jika dibuka akan menimbulkan kemungkinan pasien tidak lagi memberikan informasi selanjutnya kepada dokter; Bagi pasien, informasi tersebut itu sangat penting dan sangat sensitif; Jika dibuka rahasia tersebut, akan menimbulkan kemarahan/gejolak/sikap masyarakat yang merugikan kepentingan pengobatan pasien; Pasien tidak pernah mengizinkan secara tegas atau secara tersirat untuk dibuka rahasia tersebut (Munir Fuady, 2005:38).

\section{PEMBAHASAN}

\section{Wajib Simpan Rahasia Kedokteran dalam Hukum Positif Indonesia}

Saat seorang mahasiswa Fakultas Kedokteran telah selesai atau menyelesaikan studinya, maka akan dilaksanakan upacara pelantikan dan pengambilan sumpah dokter. Pada upacara ini dokter baru akan mengucapkan lafal sumpah dokter yang berdasarkan atas Rapat Kerja Nasional Majelis Kehormatan Etik Kedokteran (yang selanjutnya disebut MKEK) dan Majelis Pertimbangan dan Pembelaan Anggota (yang selanjutnya disebut MP2A).

Sumpah Dokter berpegang pada sumpah yang diciptakan Hippocrates, Bapak Ilmu Kedokteran. Dalam sumpah dokter yang berpegang pada sumpah Hippocrates tersebut terdapat lafal yang terkait dengan wajib simpan rahasia kedokteran. Selain terdapat dalam lafal sumpah dokter, masalah wajib simpan rahasia kedokteran juga diatur dalam Keputusan Menteri Kesehatan Republik Indonesia Nomor 434/ Men.Kes/SK/X/1983 tentang Berlakunya Kode Etik Kedokteran Indonesia (selanjutnya disebut KODEKI) bagi para dokter Indonesia.

Kewajiban akan memegang teguh Rahasia Jabatan merupakan syarat yang senantiasa harus dipenuhi untuk menciptakan suasana percaya mempercayai yang mutlak diperlukan dalam hubungan dokterpenderita. Sejak dahulu memang terdapat beberapa jabatan tertentu yang mewajibkan para pejabatnya untuk merahasiakan segala sesuatu yang bersangkutan dengan pekerjaan mereka.

Pada umumnya kewajiban seorang pejabat untuk merahasiakan hal-hal yang telah diketahuinya adalah karena tanggungjawabnya mengharuskan demikian. Untuk itulah dalam setiap pelantikan jabatan termasuk juga pelantikan dokter baru akan dilakukan upacara pengambilan sumpah dokter yang pada intinya adalah kesanggupan untuk menyimpan Rahasia Jabatan. Hal ini dirasakan penting karena kebocoran Rahasia Jabatan dapat berakibat gangguan stabilitas maupun kerugian bagi pihak lain yang dapat dituntut melalui pengadilan negeri, pengadilan militer, pengadilan administrasi dan sebagainya tergantung dari peraturan perundang-undangan yang mengaturnya. Kebocoran dari rahasia kedokteran dapat berakibat tuntutan ke pengadilan, terlebih-lebih dalam masyarakat yang sudah maju sebagaimana dewasa ini. Suatu contoh seseorang dapat kehilangan pekerjaannya karena bocornya rahasia tersebut.

Norma-norma kesusilaan yang berpokok pada Sumpah Hippocrates tersebut, jika kemudian dianggap tidak mencukupi karena banyak tergantung kepada kelakuan dan tabiat perseorangan, yang sudah barang tentu sangat berbeda-beda dan tidak selalu baik. Oleh karena itu di berbagai negeri ditegakkan norma-norma hukum. Norma-norma hukum itu pada umumnya disusun untuk memperkokoh kedudukan Rahasia Jabatannya sehingga dapat menjamin kepentingan masyarakat.

Setiap masyarakat di suatu negara manapun juga menghendaki agar mempunyai derajat kesehatan yang baik. Derajat kesehatan yang baik dapat tercapai, jika setiap anggota masyarakat dengan perasaan bebas, dapat mengunjungi dokter, mengemukakan dengan hati terbuka segala keluhan tentang penderitaan baik jasmani maupun rohani agar mendapat pengobatan yang sesuai. Rangkaian tersebut di atas itu hanya mungkin, apabila setiap penderita dapat menaruh kepercayaan sepenuhnya kepada dokternya, tanpa perasaan takut atau khawatir, bahwa dokter ini akan memberitahukan hal mengenai penyakitnya kepada orang lain. Jika kepercayaan itu tidak ada, maka tidak mustahil bahwa orang yang sakit akan segan pergi ke dokter, karena khawatir bahwa penyakitnya yang mungkin sekali ingin mereka sembunyikan, kelak diketahui oleh umum.

Perasaan takut atau khawatir itu dapat menjadi salah satu sebab penting, bahwa dalam masyarakat terdapat banyak orang sakit yaitu karena mereka segan berobat. Oleh sebab itu, rahasia jabatan dokter berarti sendi utama bagi tercapainya setiap masyarakat yang sehat.

Sementara itu perundang-undangan kita yang mengatur tentang wajib simpan rahasia kedokteran di dalam Pasal 322 Kitab Undang-Undang Hukum Pidana (yang selanjutnya disebut KUHP). Dari bunyi Pasal 322 KUHP di atas maka terdapat perbedaan antara rahasia jabatan dengan rahasia pekerjaan. Rahasia jabatan merupakan sesuatu rahasia yang 
diketahui karena jabatan atau kedudukan seseorang, seperti pegawai negeri. Adapun rahasia pekerjaan merupakan rahasia yang diketahui karena pekerjaan. Ko Tjai Sing membedakan jabatan sebagai pekerjaan pegawai negeri, dan pekerjaan untuk pekerjaan non pegawai negeri, seperti advokat, dan dokter. Apabila rahasia pekerjaan tersebut di bidang kedokteran maka disebut rahasia kedokteran (rahasia medis). Rahasia kedokteran merupakan salah satu hal yang diketahui berdasarkan informasi yang telah disampaikan pasien (termasuk juga oleh orang yang mendampingi pasien ketika berobat), termasuk juga segala sesuatu yang dilihat (diketahui) ketika memeriksa pasien. Menurut Guwandi, asal mula rahasia medis adalah dari pasien sendiri yang menceritakannya kepada dokter sehingga sewajarnyalah pasien itu sendiri dianggap sebagai pemilik rahasia medis atas dirinya sendiri, bukannya dokter (Ari Yunanto dan Helmi, 2010:53).

Dalam Pasal 48 Undang-Undang Nomor 29 Tahun 2004 tentang Praktik Kedokteran (selanjutnya disebut UU Pradok) menegaskan bahwa, Setiap dokter atau dokter gigi dalam melaksanakan praktik kedokteran diwajibkan menyimpan rahasia kedokteran; Rahasia kedokteran dapat dibuka hanya untuk kepentingan kesehatan pasien, memenuhi permintaan aparatur penegak hukum dalam rangka penegakan hukum, permintaan pasien sendiri, atau berdasarkan ketentuan perundang-undangan.

Sedangkan Pasal 51c UU Pradok menyatakan bahwa dokter dan dokter gigi dalam melaksanakan praktik kedokteran mempunyai kewajiban-kewajiban: merahasiakan segala sesuatu yang telah diketahuinya tentang si pasien, bahkan juga setelah pasien itu meninggal dunia. Pada Pasal 57 Undang-Undang Nomor 36 Tahun 2009 tentang Kesehatan (yang selanjutnya disebut UU Kesehatan) menyatakan bahwa, setiap orang berhak merahasiakan kondisi kesehatan pribadinya yang telah dikemukakan kepada penyelenggara pelayanan; dan segala hal mengenai hak-hak atas rahasia kondisi kesehatan pribadi tidak berlaku apabila: Perintah undang-undang, Perintah pengadilan, Izin yang bersangkutan, Kepentingan masyarakat, atau Kepentingan orang tersebut.

\section{Sanksi bagi Dokter yang telah Membuka Rahasia Kedokteran}

Seorang dokter yang dengan sengaja membuka rahasia yang diketahuinya tentang seorang pasien dapat dikatakan telah melanggar sumpah dan juga melakukan pelanggaran hukum. Dalam hal ini berarti dokter telah melakukan pelanggaran etikolegal. Selain telah melakukan pelanggaran etika, juga melakukan pelanggaran hukum. Adapun sanksi yang dijatuhkan pada dokter tersebut bisa berupa sanksi disipliner, sanksi pidana, sanksi perdata, sanksi administratif dan juga sanksi dari masyarakat.

Dokter yang terbukti membuka rahasia kedokteran atas penyakit pasien dapat dikenakan sanksi yaitu berupa sanksi disipliner. Tujuan hukuman disiplin yang dijatuhkan terhadap tenaga kesehatan yang didalamnya mencakup dokter yang telah melakukan kesalahan adalah untuk memperbaiki dan mendidik tenaga kesehatan yang bersangkutan. Oleh karena itu, jika hukuman disiplin dalam bidang pelayanan kesehatan diterapkan bagi tenaga kesehatan, maka akan dengan sendirinya rasa tanggung jawab yang mendalam akan mendorong mereka untuk melakukan kewajiban profesi dan mematuhi ketentuan-ketentuan hukum yang ditentukan (Amri Amir, 1997:84).

Di Indonesia terdapat dua badan yang mengemban tugas yaitu untuk mengawasi etika kedokteran, yaitu MKEK dan Panitia Pertimbangan dan Pembinaan Etik Kedokteran (yang selanjutnya disebut P3EK). Jika seorang dokter diduga telah melakukan pelanggaran etika murni tanpa pelanggaran hukum maka dia akan dipanggil oleh MKEK Ikatan Dokter Indonesia (yang selanjutnya disebut IDI) dan disidang untuk dimintai pertanggungjawaban etik maupun disiplin profesinya. Tujuannya dari persidangan MKEK adalah untuk mempertahankan akuntabilitas dan profesionalisme serta keluhuran profesi kedokteran. Saat ini memang tugas untuk menyidangkan kasus dugaan pelanggaran disiplin atau etik di kalangan kedokteran dilaksanakan oleh MKEK sebelum nantinya akan digantikan oleh Majelis Kehormatan Disiplin Kedokteran Indonesia (yang selanjutnya MKDKI), sesuai dengan yang diatur oleh UU Pradok.

Terkait dengan sanksi pidana, pada pembahasan sebelumnya sudah diulas bahwa hal itu diatur dalam Pasal 322 KUHP. Pembocoran rahasia yang wajib disimpan karena jabatan atau pekerjaan ini merupakan delik aduan, dimana jika kejahatan dilakukan terhadap seseorang tertentu, maka perbuatan itu hanya dapat dituntut atas pengaduan orang itu.

Kewajiban menyimpan rahasia pasien diatur di dalam UU Pradok yang diberlakukan sejak tanggal 6 Oktober 2005. Dengan adanya ketentuan di dalam UU Pradok sebagai lex specialis, maka Pasal 322 KUHP ini tidak berlaku lagi bagi dokter dan dokter gigi, tetapi tetap diberlakukan bagi tenaga kesehatan di luar dokter dan dokter gigi. Namun di dalam praktik, masih dimungkinkan dicantumkannya Pasal 322 KUHP ini sebagai tuntutan subsider oleh penuntut umum (Anny Isfandyarie dan Fachrizal Afandi, 2006:116). 
Terhadap seorang dokter yang membuka rahasia pasiennya juga dapat dikenai sanksi perdata. Pasien tersebut dapat mengajukan gugatan berdasar Pasal 1365 KUHPerdata, dan sanksi administratif juga dapat juga dijatuhkan kepada dokter yang melakukan pelanggaran atas wajib simpan rahasia kedokteran. Berpedoman pada Undang-Undang Nomor 36 Tahun 2009 tentang Kesehatan (yang selanjutnya disebut UU Kedokteran), sanksi itu diatur dalam Pasal 188 ayat (1).

Adapun tindakan administratif bagi dokter yang melakukan pelanggaran sebagaimana dimaksud pada Pasal 188 ayat (1) di atas diatur dalam Pasal 188 ayat (3) UU Kedokteran berupa peringatan secara tertulis dan pencabutan izin sementara atau izin tetap.

Jika dokter yang telah melakukan pelanggaran merupakan PNS atau TNI/Polri maka selain tunduk kepada peraturan-peraturan dalam hukum kesehatan juga terikat pada Peraturan Menteri Kesehatan RI Nomor 415/Menkes/Per.IV/1987 tentang Peningkatan Efisiensi Kerja pada Tenaga Medik di Rumah Sakit Pemerintah itu. Tenaga kesehatan yang melakukan kesalahan dan atau kelalaian, disamping dikenakan hukuman sesuai Peraturan Pemerintah Nomor 30 Tahun 1980 tentang Disiplin Pegawai Negeri Sipil, dikenakan tindakan administratif sebagai sanksi oleh pimpinan yang diberi kewenangan untuk menindak. Adapun jenis tindakan yang diambil dapat berupa teguran lisan, teguran tertulis maupun pencabutan rekomendasi atau izin untuk melaksanakan praktik dalam jangka waktu tertentu, selama-lamanya satu tahun. Terakhir yang juga tidak kalah pentingnya adalah sanksi dari masyarakat terhadap dokter yang terbukti melakukan pelanggaran rahasia kedokteran. Tidak ada lagi kepercayaan terhadap dokter tersebut dan masyarakat juga akan menjauhinya.

\section{Pengecualian terhadap Wajib Simpan Rahasia Kedokteran}

Apakah rahasia kedokteran itu boleh dibuka? Terkait dengan hal ini ada dua pendapat yang saling bertentangan yaitu pendirian absolut dan pendirian nisbi. Bagi mereka yang menganut pendirian yang absolut maka rahasia kedokteran ini akan disimpan dan dirahasiakan selamanya tanpa pengecualian. Menurut pendapat penulis, si penganut pendirian absolut ini sangat kaku dan juga tidak memahami bahwa tujuan rahasia kedokteran itu adalah untuk menyehatkan masyarakat sehingga dengan alasanalasan tertentu boleh dibuka. Beda dengan penganut pendirian nisbi yang akan selalu mempertimbangkan kepentingan umum yang lebih utama yang harus diperhatikan daripada kepentingan pasien. Memang harus diakui bahwa dokter yang menganut pendirian nisbi akan mengalami kesulitan dan juga pertentangan dalam batinnya jika mengambil keputusan untuk membuka atau menyimpan rahasia kedokteran yang menimbulkan dilema ini.

Penulis menganut pendirian nisbi sehingga dapat berpendapat bahwa wajib simpan rahasia kedokteran tidak bersifat absolut. Ada beberapa keadaan yang dapat dijadikan alasan rahasia kedokteran tersebut dibuka. Beberapa ahli telah mencoba menggolongkan beberapa keadaan dimana dokter dapat membuka rahasia kedokteran menjadi dua golongan: Dengan kerelaan atau pun izin pasien. Pasien dianggap telah menyatakan secara tidak langsung bahwa rahasia kedokteran itupun bukan lagi merupakan rahasia, sehingga tidak wajib dirahasiakan lagi; Pembukaan rahasia tanpa izin si pasien. Dalam hal ini dokter terpaksa membuka rahasia kedokteran karena adanya dasar penghapusan pidana (strafuitsluitingsgroden) yang diatur dalam Pasal 48 KUHP, Pasal 50 KUHP dan Pasal 51 KUHP (Abdul Mun'im Idries dan Agung Legowo Tjiptomartono, 2008:253).

Dari bunyi tiga pasal dalam KUHP sebagaimana di atas itu dapat kita ketahui bahwa wajib simpan rahasia kedokteran dikecualikan dalam keadaan daya paksa, melaksanakan ketentuan undang-undang dan melaksanakan perintah jabatan. Pengecualian terhadap wajib simpan rahasia kedokteran juga diatur dalam Pasal 48 ayat (2) UU Pradok dan Pasal 57 ayat (2) UU Kedokteran.

Dari pembahasan di atas maka diketahui bahwa alasan yang dapat dipergunakan oleh dokter untuk dapat membuka rahasia kedokteran adalah sebagai berikut:

Pertama, Adanya izin dari pasiennya. Rahasia kedokteran ini merupakan hak dan milik pasien, jadi hanya pasien tersebut yang berhak memutuskan apakah orang lain boleh mengetahui kondisinya atau tidak. Contoh kasus: Seorang pasien yang tidak masuk kerja karena sakit lalu minta surat keterangan sakit untuk dilaporkan pada tempatnya bekerja.

Kedua, Adanya pengaruh daya paksa. Daya paksa disini bersifat relatif, yang terjadinya karena kondisi darurat. Jika kondisi ini tidak ada maka keadaan daya paksa tersebut juga tidak ada. Contoh kasus: Seorang sopir menderita epilepsi. Dokter terpaksa membuka rahasia penyakit itu pada sang majikan sopir tersebut.

Ketiga, Adanya peraturan perundang-undangan. Secara formil justifikasinya karena terdapat pada perundang-undangan dan secara materiil juga sudah 
dipertimbangkan oleh undang-undang bahwa ada kepentingan yang lebih besar. Contoh kasus: Seorang dokter yang diminta membuat Visum et Repertum.

Keempat, Adanya perintah jabatan. Contoh kasus untuk menjelaskan kondisi ini adalah seorang dokter penguji kesehatan yang diharuskan melaporkan hasil kesehatan pasien yang diperiksanya kepada institusi yang meminta dan hal ini tanpa memberitahukan terlebih dahulu kepada pasien tersebut.

Kelima, Demi kepentingan umum. Disini rahasia kedokteran terpaksa dibuka karena ada kepentingan yang lebih diutamakan, yaitu masyarakat umum. Contoh kasus: Dokter melaporkan pasiennya seorang penjahat yang mendapat luka-luka.

Alexandra Indriyanti menyebutkan beberapa hal yang merupakan pengecualian wajib simpan rahasia kedokteran, yaitu: Syarat keterbatasan para pihak yang relevan saja, misalnya kepada suami atau istri, mantan suami atau istri, pengadilan, pihak yang mungkin akan ketularan atau terpapar penyakit tersebut; dan keterbatasan informasi, yakni hanya dibuka sejauh yang diperlukan; serta keterbatasan persyaratan, yakni informasi hanya dibuka apabila memang secara medis, informasi tersebut layak dibuka.

Pengecualian terhadap wajib simpan rahasia kedokteran berlaku pada kondisi-kondisi darurat seperti wabah dan bencana alam, seorang dokter atau pun petugas kesehatan itu tidak boleh membiarkan bencana terjadi tanpa penanganan yang semestinya. Hal ini diatur dalam Undang-Undang Nomor 6 Tahun 1962 tentang Wabah. Undang-undang ini mewajibkan dokter atau tenaga kesehatan untuk segera melaporkan kondisi-kondisi luar biasa karena wabah penyakit dan penyebarannya sehingga segera bisa ditanggulangi (Ari Yunanto dan Helmi, 2010:56).

\section{Kewajiban Hukum sebagai Saksi Ahli}

Dalam melaksanakan tugas-tugas sesuai dengan profesinya, seorang dokter bisa diminta bantuannya oleh penegak hukum. Hal itu terkait dengan perkara yang menyangkut tubuh dan atau nyawa manusia. Pendapat atau bantuan dokter ini dibutuhkan dalam rangka menemukan kebenaran materiil atas perkara pidana karena sang pemutus perkara yaitu hakim tidak memiliki ilmu yang terkait dengan anatomi tubuh manusia. Idealnya adalah memang para penegak hukum juga harus memiliki pengetahuan kedokteran sehingga bila menghadapi kasus yang terkait dengan perusakan tubuh dan nyawa manusia maka mereka dapat menilai sendiri secara obyektif. Selain itu sistem pemeriksaan medikolegal di negara kita menganut sistem continental dimana tidak terdapat petugas khusus yang melakukan pemeriksaan medikolegal sebagaimana yang telah terdapat pada sistem medical examiner maupun sistem coroner. Sebelum kita ulas tentang kewajiban hukum dokter sebagai saksi ahli, maka terlebih dahulu penulis akan mengulas pengertian beberapa istilah yang digunakan dalam pembahasan materi ini dan juga prosedur beracara dalam penegakan hukum pidana.

Menurut Pasal 183 Kitab Undang-Undang Hukum Acara Pidana (yang selanjutnya disebut KUHAP), hakim dalam menjatuhkan putusan pidana sekurangkurangnya berdasarkan dua alat bukti sah, yang dapat membentuk keyakinan para hakim tentang kesalahan terdakwa. Terbentuknya keyakinan hakim dalam menjatuhkan putusan pidana didasarkan pada hasil pemeriksaan alat-alat bukti yang diketemukan pada proses persidangan. Sementara itu menurut Pasal 184 KUHAP alat bukti yang sah adalah keterangan saksi, keterangan ahli, surat, petunjuk, dan keterangan terdakwa.

Menurut Pasal 1 angka 27 KUHAP keterangan saksi merupakan salah satu alat bukti dalam perkara pidana yang berupa keterangan dari saksi mengenai suatu peristiwa pidana yang ia dengar sendiri, ia lihat sendiri, dan ia alami sendiri dengan menyebut alasan dari pengetahuannya, dan pada Pasal 1 angka 28 KUHAP keterangan ahli merupakan keterangan yang diberikan oleh seorang yang memiliki keahlian khusus tentang hal yang diperlukan untuk membuat terang tentang suatu perkara pidana guna kepentingan pemeriksaan.

Jika terdapat perbedaan antara keterangan saksi dengan keterangan ahli. Keterangan saksi, diberikan berdasarkan pada hal yang dilihat, didengar atau dialami sendiri; sedangkan pendapat atau sangkaan yang telah diperoleh dari hasil pemeriksaan bukanlah merupakan keterangan saksi. Seorang ahli dalam memberikan keterangan diminta untuk mengajukan pendapatnya menurut pengetahuannya itu. Namun demikian, semua ketentuan yang telah berlaku untuk saksi juga berlaku untuk ahli, termasuk dokter yang memberikan keterangan ahli (Y.A. Triana Ohoiwutun, 2006:38).

Pengertian tentang saksi ahli dapat dijelaskan lebih lanjut dalam KUHAP sebagaimana tertuang dalam Pasal 186 KUHAP. Di dalam penjelasan pasal ini dinyatakan bahwa keterangan ahli ini dapat juga sudah diberikan pada waktu pemeriksaan oleh penyidik atau penuntut umum yang dituangkan dalam suatu bentuk laporan, dibuat dengan mengingat sumpah di waktu ia menerima jabatan atau pekerjaan, jika hal itu tidak diberikan pada waktu pemeriksaan oleh penyidik atau 
penuntut umum, maka pada pemeriksaan di sidang, diminta untuk memberikan keterangan dan dicatat dalam berita acara pemeriksaan, keterangan tersebut diberikan setelah ia mengucapkan janji atau sumpah di hadapan hakim.

Keterangan ahli, menurut Pasal 186 KUHAP dapat diberikan pada tingkat penyidikan atau penuntutan secara tertulis berdasarkan sumpah pekerjaan atau jabatan. Namun demikian, pada proses pemeriksaan di persidangan saksi ahli diwajibkan untuk mengucapkan sumpah atau janji seperti ditentukan dalam Pasal 179 ayat (2) KUHAP, yaitu akan memberikan keterangan sebaik-baiknya dan yang sebenar-benarnya menurut pengetahuan dalam bidang keahliannya (Y.A. Triana Ohoiwutun, 2006:40).

Kriteria untuk dapat ditunjuk sebagai seorang ahli dalam perkara pidana tidak ditentukan dalam KUHAP. Menurut KUHAP, keterangan ahli ialah apa yang seorang ahli nyatakan di sidang pengadilan, sedangkan keterangan ahli ini adalah keterangan yang diberikan oleh seorang yang memiliki keahlian khusus. Kriteria memiliki keahlian khusus sebagai seorang ahli tidak dijelaskan terperinci, misalnya berhubungan dengan ilmu pengetahuan yang telah dipelajari, atau pengalaman yang dimiliki tentang sesuatu hal. Penjelasan kelayakan sebagai seorang yang telah memiliki keahlian khusus perlu diberikan. Misalnya, penilaiannya akan ditentukan berhubungan dengan ilmu pengetahuan yang telah dipelajari dan atau pengalaman yang telah dilakukan pada bidang tertentu (Y.A. Triana Ohoiwutun, 2006:40-41).

Kriteria sebagai saksi ahli dalam hukum pidana itu ditentukan expert withness one who by reasons of education or specialized experience possesses superior knowledge respecting a subject about which persons having no particular training are incapable of forming an accurate opinion or deducing correct conciissions. Seseorang karena pendidikannya atau pengalamannya khusus memiliki pengetahuan yang tinggi tentang suatu pokok masalah, sehingga dapat membentuk pendapat yang tepat atau mengambil kesimpulan yang benar. Di samping itu, California Evidence Code menentukan seorang ahli sebagai a person is qualified to testify as an expert if he has special knowledge, skill, experience, training, or education sufficient to qualify him as an expert on the subject to which his testimony relates. Seseorang dapat memberi keterangan sebagai ahli jika ia mempunyai pengetahuan, keahlian, pengalaman, latihan atau pendidikan khusus yang memadai untuk memenuhi syarat sebagai seorang ahli tentang hal yang berkaitan dengan keterangannya. Dengan demikian, penjelasan syarat kriteria seseorang dapat ditentukan sebagai saksi ahli dalam KUHAP perlu dilengkapi (Y.A.Triana Ohoiwutun, 2006:41-42).

Pelaksanaan terhadap penegakan hukum pidana di Indonesia dimulai dari suatu tahap yang disebut tahap penyelidikan. Lalu tahap polisi mencari dan menemukan apakah suatu peristiwa terkait dengan suatu delik pidana, sehingga polisi akan menentukan dapat atau tidaknya dilakukan suatu penyidikan. Pada tahap penyelidikan, polisi menerima laporan atau pengaduan dari seseorang tentang adanya tindak pidana, mencari keterangan dan barang bukti. Bila dianggap perlu, atas perintah penyidik, penyelidik dapat pula melakukan tindakan berupa penangkapan, larangan meninggalkan tempat, penggeledahan dan penyitaan, pemeriksaan dan penyitaan surat. Bila polisi menemukan bahwa suatu peristiwa terkait dengan suatu delik pidana, maka penyelidikan akan diteruskan dengan tahapan penyidikan. Pada tahap penyidikan, polisi penyidik atau penyidik pembantu akan mencari serta mengumpulkan bukti, menemukan tersangka, atau orang-orang yang terlibat di dalamnya, dan bila bukti dan berkas-berkasnya telah lengkap, polisi akan menyerahkannya pada kejaksaan. Pada tahap penyidikan polisi dapat meminta bantuan dokter sesuai dengan surat permintaan visum et repertum, maka hasil pemeriksaan adalah alat bukti, bukan rahasia kedokteran. Keadaan pemeriksaan dilakukan tanpa surat permintaan visum et repertum, maka hasil pemeriksaan adalah rahasia kedokteran yang harus dicatat dengan teliti dan dicantumkan dalam rekam medis. Bila polisi menganggap perlu dan mengeluarkan surat permintaan visum et repertum, maka korban akan diperiksa kembali berdasarkan keadaan saat surat permintaan visum et repertum diterbitkan.

Keterangan atas keadaan medis pada saat kejadian telah dicatat dalam rekam medis dapat dijadikan alat bukti dengan merangkumnya dalam surat keterangan dokter atau surat keterangan ahli. Polisi pada tahap ini juga dapat mendatangkan seorang ahli termasuk dokter yang diperlukan dalam hubungannya dengan pemeriksaan perkara untuk memberikan keterangan pada polisi yang hasilnya dituangkan melalui berita acara pemeriksaan. Tahap pertama penyidik hanya menyerahkan berkas perkara, dalam hal penyidikan sudah dianggap selesai, penyidik akan menyerahkan tanggung jawab atas tersangka dan barang bukti kepada penuntut umum. Pada tahap pemeriksaan di pengadilan, baik jaksa penuntut umum maupun penasehat hukum tersangka dapat menghadirkan saksi atau ahli dengan izin hakim (Abdul Mun'im 
Idries dan Agung Legowo Tjiptomartono, 2008:254255). Selanjutnya peranan dokter dalam membantu menemukan kebenaran materiil untuk penegakan hukum pidana terdapat dalam Pasal 133 dan 179 KUHAP.

Dalam hal penyidik untuk kepentingan peradilan menangani seorang korban baik luka, keracunan atau pun mati yang diduga karena peristiwa yang merupakan tindak pidana, ia berwenang mengajukan permintaan keterangan ahli kepada ahli kedokteran dan kehakiman atau dokter dan atau ahli lainnya; Permintaan keterangan ahli dilakukan secara tertulis, yang dalam surat itu disebutkan dengan tegas untuk pemeriksaan luka atau pemeriksaan mayat dan atau pemeriksaan bedah mayat; Mayat yang dikirim pada ahli kedokteran kehakiman atau dokter pada rumah sakit harus diperlakukan secara baik dengan penuh penghormatan terhadap mayat tersebut dan diberi label yang memuat identitas mayat, dilak dan dengan diberi cap jabatan yang dilekatkan pada ibu jari kaki atau bagian lain badan mayat.

Setiap orang yang diminta pendapatnya sebagai ahli kedokteran kehakiman atau dokter atau ahli lainnya wajib memberikan keterangan ahli demi keadilan. Semua ketentuan untuk saksi berlaku juga bagi yang akan memberikan keterangan ahli, dengan ketentuan bahwa mereka mengucapkan sumpah atau janji dan akan memberikan keterangan yang sebaikbaiknya dan yang sebenarnya menurut pengetahuan dalam bidang keahliannya.

Kewajiban dokter untukmemberikan kesaksian diatur dalam Pasal 224 KUHP apabila setiap orang secara sah dipanggil sebagai saksi, ahli atau sebagai juru bahasa, dan dengan sengaja tidak memenuhi suatu kewajiban yang menurut undang-undang, maka diancam dalam perkara pidana, dengan pidana penjara paling lama sembilan bulan; dalam perkara lain, dengan pidana penjara paling lama enam bulan.

\section{Wajib Simpan Rahasia Kedokteran Vs Kewajiban Hukum sebagai Saksi Ahli}

Sampailah kita pada pertarungan antara wajib simpan rahasia kedokteran versus kewajiban hukum sebagai saksi ahli. Dalam uraian sebelumnya kita pahami bahwa dokter diwajibkan untuk menyimpan rahasia tentang diri pasien yang diperiksanya, bahkan setelah sang pasien tersebut meninggal dunia. Hal itu sesuai dengan sumpah yang diucapkannya dan diatur juga dalam KODEKI. Perundang-undangan juga memberikan ancaman sanksi pidana, sanksi perdata maupun sanksi administratif bagi dokter yang melakukan pelanggaran wajib simpan rahasia kedokteran. Disisi lain juga terdapat peraturan yang mewajibkan seorang dokter memberikan bantuan pada pengadilan yaitu sebagai saksi ahli yang juga disertai sanksi pidana jika dokter tidak memenuhi kewajiban tersebut. Pasal 224 KUHP mewajibkan untuk memberikan kesaksian, sementara Pasal 322 KUHP justru mengharuskan adanya kewajiban untuk menyimpan rahasia tentang hal-hal yang dilihat dan diketahui terkait jabatan dan pekerjaannya.

Menurut pendapat Adami Chazawi, dalam perkara pidana, jika pengadilan meminta pada dokter sebagai ahli memberikan keterangan yang di dalamnya ada keterangan yang wajib disimpannya, misalnya tentang penyakit yang telah menyebabkan pasien meninggal, tidak dipidana. Hal ini bukan berarti dokter tersebut tidak melakukan tindak pidana sebagaimana rumusan Pasal 322 KUHP, tetapi tidak dipidananya perbuatan memberikan keterangan ahli dikarenakan kehilangan sifat melawan hukumnya perbuatan. Pertimbangan hukumnya ialah apabila dokter nekat bertahan pada rahasia jabatan di depan sidang pengadilan maka ia melanggar kepentingan hukum yang lebih besar yang berupa kepentingan hukum untuk tegaknya keadilan (Adami Chazawi, 2007:142).

Pendapat tersebut di atas menurut Ari Yunanto dan Helmi dianggap tidak tepat. Dalam kasus disebutkan bahwa dokter diminta keterangannya sebagai ahli, bukan sebagai saksi. Seseorang atau siapapun yang diminta keterangannya sebagai ahli, memberikan keterangan yang tidak bersifat faktual melainkan berdasarkan keahliannya pada bidang-bidang tertentu. Keterangan diberikan berdasarkan keilmuan yang dimilikinya. Hal ini berbeda dengan bila diminta keterangan sebagai saksi, yang mana keterangan diberikan berdasarkan fakta yang dilihat, didengar dan dialaminya. Jadi tidak mungkin seorang dokter yang diminta keterangannya sebagai ahli akan memberikan penjelasan yang bersifat faktual seperti penyakit atau keadaan seseorang. Mengenai penyakit atau keadaan seseorang yang sakit merupakan suatu hal yang bersifat faktual yang harus dirahasiakan dokter. Sedangkan keterangan sebagai ahli yang diberikan dokter bukanlah rahasia, karena substansinya ialah menyangkut ilmu pengetahuan, yang bukan obyek yang harus dirahasiakan (Ari Yunanto dan Helmi, 2010:54-55).

Berbeda dengan apabila dokter tersebut diminta keterangannya sebagai saksi. Dalam hal ini akan terjadi dilema bagi dokter tersebut, antara keharusan menyimpan suatu rahasia kedokteran dan keharusan memberikan keterangan sebagai saksi. Kewajiban memberikan kesaksian ini merupakan kewajiban 
hukum setiap orang, bahkan pelanggaran terhadap kewajiban ini dikriminalisasi berdasarkan Pasal 224 KUHP. Dalam kasus demikian dokter juga dapat memilih untuk melaksanakan kewajiban menyimpan rahasia kedokteran, yang berarti ia tidak bersedia memberi keterangan sebagai saksi. Atas pilihan itu seorang dokter tidak dapat dipidana, karena hukum pidana materiil telah disediakan alasan pembenar (rechtwaardigingsgronden) yang di dalam hal ini adalah noodtoestand atau keadaan darurat (terpaksa). Pada kasus tersebut dokter dihadapkan pada konflik antara dua kewajiban, yaitu kewajiban menyimpan rahasia kedokteran dan kewajiban untuk memberi keterangan sebagai ahli, yang mana ia harus memilih untuk melaksanakan satu kewajiban, yaitu memberi keterangan sebagai saksi (Ari Yunanto dan Helmi, 2010:55).

Dalam perspektif hukum pidana formal (hukum acara pidana), telah disediakan pula hak untuk undur diri atau verschoningrecht sebagai saksi atau ahli sebagaimana terdapat dalam Pasal 170 KUHAP: Mereka yang karena pekerjaannya, harkat martabat, atau jabatannya diwajibkan menyimpan rahasia, dapat minta dibebaskan dari kewajiban sebagai saksi, yaitu tentang hal yang dipercayakan kepada mereka; Hakim menentukan sah tidaknya segala alasan permintaan tersebut.

Atas dasar hak undur diri sebagai saksi atau ahli tersebut, maka seorang dokter tetap dapat menyimpan rahasia kedokteran, namun hak tersebut tidaklah bersifat mutlak, karena permintaan mundur sebagai saksi atau ahli tergantung pada penilaian hakim. Artinya, apabila hakim memandang kesaksian atau keterangan ahli dari dokter tersebut sangat penting (menentukan) dalam memutus perkara itu, maka hakim dapat menolak permintaan mundur sebagai saksi atau ahli (Ari Yunanto dan Helmi, 2010:56).

Menurut Pasal 168 KUHAP hak undur diri adalah untuk memberi keterangan saksi pada pemeriksaan di sidang pengadilan dapat digunakan setiap orang saat pemeriksaan di pengadilan, apabila: Saksi adalah keluarga sedarah atau semenda dalam garis lurus ke atas atau ke bawah sampai derajat ketiga dari terdakwa atau yang sama-sama sebagai terdakwa; Saudara dari terdakwa atau yang sama-sama sebagai terdakwa, saudara ibu dan/atau saudara dari bapak, juga mereka yang mempunyai hubungan karena perkawinan dari anak-anak saudara terdakwa sampai derajat ketiga; Suami atau istri terdakwa meskipun sudah bercerai dan/atau yang sama-sama sebagai terdakwa.

Harus diingat bahwa hak undur diri atau oleh beberapa ahli disebut hak tolak ungkap digunakan bila seorang dokter atau tenaga kesehatan memberikan keterangan saksi pada tahap pemeriksaan di sidang pengadilan. Permintaan memberikan keterangan ahli atau permintaan keterangan dalam pemeriksaan pada tahap sebelum pemeriksaan sidang di pengadilan, tidak dapat diabaikan dengan mengasumsikan dokter atau tenaga kesehatan memiliki hak undur diri (Abdul Mun'im Idries dan Agung Legowo Tjiptomartono, 2008:256). Sampai saat ini ada 4 (empat) jabatan yang diwajibkan menyimpan rahasia, yaitu pemuka agama atau rohaniwan, dokter, advokat, dan notaris. Dokter dipandang sebagai pemegang rahasia yang utama dan tidak perlu lagi dipersoalkan.

Mengakhiri pembahasan tentang wajib simpan rahasia kedokteran versus kewajiban hukum sebagai saksi ahli ini maka penulis akan melengkapi dengan satu ilustrasi kasus sebagaimana di bawah ini.

Seorang dokter mempunyai pasien penderita HIV/ AIDS. Pasien tersebut meminta dengan sangat agar dokter merahasiakan hal itu jangan sampai orang lain mengetahuinya, keluarganya sekalipun. Jelas sekali bahwa dalam kasus ini dokter berada pada posisi yang sulit dan dilematis. Penyakit HIV/AIDS berbahaya dan dapat menular sementara pasien tidak setuju jika rahasia tersebut dibuka.

Saat ini di negara kita peraturan hukum tentang HIV/AIDS belum dibuat dalam suatu perundangundangan yang khusus. Ketentuan yang ada hanya berpedoman pada Instruksi Menteri Kesehatan RI Nomor 72/Menkes/Instll/1988 tentang Kewajiban Melaporkan Penderita dengan Gejala-gejala AIDS. Ketentuan tersebut hanya ditujukan kepada petugas kesehatan dan juga sarana pelayanan kesehatan saja. Adapun tindakan yang diambil hanyalah pelaporan kepada Direktorat Jenderal Pemberantasan Penyakit Menular dan Penyehatan Lingkungan Pemukiman dengan memperhatikan kerahasiaan pribadi; dan Surat Keputusan Menko Kesra Nomor 9 Tahun 1994 tentang Strategi Nasional Penanggulangan HIV/AIDS.

Setiap pemeriksaan untuk mendiagnosis HIV/ AIDS diharuskan didahului dengan penjelasan yang benar dan mendapat persetujuan yang bersangkutan. Sebelum dan sesudahnya harus diberikan konseling yang memadai dan hasil pemeriksaan wajib untuk dirahasiakan. Menyikapi kasus-kasus sebagaimana digambarkan di atas itu, maka pilihan mana yang harus diambil. Apakah kita harus mengedepankan Hak Asasi Manusia (HAM) dari si penderita HIV/ AIDS tersebut yaitu dengan mengorbankan kesehatan masyarakat yang seharusnya juga dilindungi, dan bagaimana dengan istri atau suami dan anak-anak penderita jika mereka tertular. Dalam hal ini memang 
terdapat benturan antara kepentingan perseorangan dengan kepentingan masyarakat. Tentunya yang harus dijadikan pertimbangan adalah kepentingan mana yang lebih utama. Selain itu juga harus dipahami bahwa HAM tidaklah bersifat absolut karena dalam kehidupan bermasyarakat hak asasi seseorang juga merupakan hak asasi orang lain di dalam masyarakat tersebut. Jalan terbaik adalah dokter secara persuasif berupaya agar pasien bersedia untuk dibuka rahasia tentang penyakitnya dengan memberikan penjelasan bahwa hal tersebut demi kepentingan umum sehingga pasien tersebut harus mengalah. Jika pasien tersebut tetap bertahan bahwa rahasia akan penyakitnya tidak boleh disebarluaskan, maka hal itu bisa berdampak meningkatnya jumlah penderita HIV/AIDS. Hal yang pasti tidak kita harapkan.

\section{PENUTUP}

\section{Kesimpulan}

Demikianlah pembahasan tentang wajib simpan rahasia kedokteran versus kewajiban hukum sebagai saksi ahli yang merupakan salah satu problema dan pilihan yang dilematis bagi dokter. Mengakhiri tulisan ini dapat diambil beberapa simpulan sebagai berikut: Rahasia kedokteran tidak bersifat absolut dan dapat dibuka pada beberapa keadaan tertentu yaitu: atas permintaan pasien itu sendiri, karena daya paksa, memenuhi peraturan perundang-undangan, adanya perintah jabatan dan demi kepentingan umum; Legal forensik sangat cukup kuat sebagai alat bukti di muka pengadilan; Dokter dapat menggunakan hak undur diri sebagai saksi ahli di persidangan, namun permintaan mundur ini tergantung pada penilaian hakim. Hakim dapat menolak permintaan dokter jika keterangan ahli tersebut sangat menentukan dalam perkara itu.

\section{Rekomendasi}

Adapun masukan yang dapat penulis sampaikan bagi para pengemban profesi kedokteran adalah, sebagai dokter hendaknya memahami dan mentaati peraturan hukum kedokteran/peraturan lain bidang hukum sehingga terhindar dari pelanggaran etika kedokteran maupun pelanggaran hukum, khususnya pelanggaran wajib simpan rahasia kedokteran; Jika seorang dokter terpaksa membuka rahasia kedokteran, itu semata-mata demi memenuhi kewajiban hukum serta mengutamakan kepentingan umum.

\section{DAFTAR PUSTAKA}

Buku:

Amir, Amri, 1997, Bunga Rampai Hukum Kesehatan, Jakarta: Widya Medika.
Chazawi, Adami, 2007, Malpraktik Kedokteran, Malang: Bayumedia.

Fuady, Munir, 2005, Sumpah Hippocrates (Aspek Hukum Malpraktik Dokter), Bandung: Citra Aditya Bakti.

Hariyani, Safitri, 2005, Sengketa Medik Alternatif Penyelesaian Perselisihan antara Dokter dengan Pasien, Jakarta: Diadit Media.

Idries, Abdul Mun'im dan Agung Legowo Tjiptomartono, 2008, Penerapan Ilmu Kedokteran Forensik dalam Proses Penyidikan, Jakarta: Sagung Seto.

Isfandyarie, Anny dan Fachrizal Afandi, 2006, Tanggung Jawab Hukum dan Sanksi bagi Dokter Buku ke II, Jakarta: Prestasi Pustaka Publisher.

Isfandyarie, Anny, 2005, Malpraktik dan Risiko Medik dalam Kajian Hukum Pidana, Jakarta: Prestasi Pustaka Publisher.

Komalawati, D. Veronica, 1989, Hukum dan Etika dalam Praktik Dokter, Jakarta: Sinar Harapan.

Nasution, Bahder Johan, 2005, Hukum Kesehatan Pertanggungjawaban Dokter, Jakarta: Rineka Cipta.

Ohoiwutun, Y.A. Triana, 2006, Profesi Dokter dan Visum et Repertum (Penegakan Hukum dan Permasalahannya), Malang: Dioma.

Soewono, Hendrojono, 2007, Batas Pertanggungjawaban Hukum Malpraktik Dokter dalam Transaksi Terapeutik, Surabaya: Srikandi.

Supriadi, Wila Chandrawila, 2001, Hukum Kedokteran, Bandung: Mandar Maju.

Wiradharma, Danny, 1996, Penuntun Kuliah Hukum Kedokteran, Jakarta: Binarupa Aksara.

Yunanto, Ari dan Helmi, 2010, Hukum Pidana Malpraktik Medik Tinjauan dan Perspektif Medikolegal, Yogyakarta: Andi Offset.

\section{Peraturan Perundang-undangan:}

Kitab Undang-Undang Hukum Perdata.

Kitab Undang-Undang Hukum Pidana.

Kitab Undang-Undang Hukum Acara Pidana.

Undang-Undang Nomor 29 Tahun 2004 tentang Praktik Kedokteran.

Undang-Undang Nomor 36 Tahun 2009 tentang Kesehatan.

Peraturan Pemerintah Nomor 10 Tahun 1966 tentang Wajib Simpan Rahasia Kedokteran.

Peraturan Pemerintah Nomor 30 Tahun 1980 tentang Disiplin Pegawai Negeri Sipil.

Peraturan Menteri Kesehatan Nomor 415/Menkes/ Per.IV/1987 tentang Peningkatan Efisiensi Kerja Tenaga Medik di Rumah Sakit Pemerintah. 